\section{Association between Dental Caries and Socioeconomic Factors in Schoolchildren - A Multilevel Analysis}

\author{
Janessa Luiza Engelmann, Fernanda Tomazoni, Marta Dutra Machado \\ Oliveira, Thiago M. Ardenghi
}

Department of Stomatology, School of Dentistry, UFSM Universidade Federal de Santa Maria, Santa Maria, RS, Brazil

Correspondence: Janessa Luiza Engelmann, Rua Marechal Floriano Peixoto, 1184, 97015-372 Santa Maria, RS, Brasil. Tel: +55-55-81288920. e-mail: jluiza@hotmail.com

\begin{abstract}
This study aimed to assess the association between dental caries, socioeconomic individual and contextual factors in 12-years-old children. A representative sample of 1,134 children enrolled in public schools from Santa Maria, RS, Brazil, was obtained from a multistage random sampling. Four calibrated dentists examined participants at schools. Data about dental caries (DMF-T index) and dental plaque (present or absent) were assessed. Children's parents or guardians answered questions regarding their demographics and socioeconomic status. Context variables were also collected from official publications of the city. Data analyses were performed using multilevel logistic regression models. Caries prevalence in this sample (DMF-T $\geq 1$ ) was $49.9 \%$ (95\%Cl: 45.05\% - 54.77\%), and mean DMF-T was 1.15 (95\% Cl: $1.01-1.29)$ with 0.068 standard error. Children of the $3^{\text {rd }}$ and $2^{\text {nd }}$ tertile of income represented by the rich and intermediate categories, showed, respectively, a 50\% (OR 0.50: CI95 \% 0.35-0.71) and 39\% (OR 0.61: CI95\% 0.45-0.82) lower chance to present untreated caries compared with the poorest portion of the sample represented by the $1^{\text {st }}$ tertile of income. Regarding the context covariates, children from lower income neighborhood presented a higher chance for having untreated dental caries compared with their counterpart (OR 1.70: CI95\% 1.19 to 2.43). Inequalities in the distribution of dental caries continue affecting children from poorer socioeconomic profiles. There is need for planning public interventions for oral health promotion that take into account individual and contextual socioeconomic characteristics.
\end{abstract}

Key Words: children, dental caries, multilevel analysis.

\section{Introduction}

Although the etiological role of sugar, microorganism and tooth susceptibility for dental caries is well known (1), socioeconomic inequalities at individual and community levels have been highlighted as major determinants for the occurrence of the disease (2). Therefore, the planning of oral health promotion aimed at reducing health inequalities should tackle these underlying socioeconomic causes of dental caries (3).

In Brazil, data from national population-based oral health surveys have shown an increase in the prevalence of caries-free 12 years-old children from 31\% to 44\% from 2003 to 2010 (4). However, despite the decline in caries prevalence in the last years, the distribution of the disease occurs unevenly between individuals (5). The literature has shown a nonhomogeneous distribution of the disease, where individuals or communities with better socioeconomic profiles presented lower values of DMF-T and higher percentage of caries-free children (6). Thus, the highest levels of disease were observed in those parts of the population that live in social deprivation (7).

Studies assessing the associated factors for dental caries have been largely focused on the influence of socioeconomic conditions $(2,7)$. However, it is important to assess the variability of caries distribution taking into account the hierarchy of interrelationships between the individual factors and the environment where individuals are living (8).

The inequality in the occurrence of the disease may be related to a more intense exposure to common risk factors, since individuals who live in the same context tend to have similar behaviors $(9,10)$. However, most studies that consider the contextual features have focused on adult and elderly population $(9,11)$. There is lack of studies assessing the individual and context factors associated to the occurrence of dental caries in the child and adolescent populations (10).

This study aimed to assess the effect of socioeconomic variables from individual and context levels in the occurrence of dental caries and untreated dental caries in 12-years-old children in Brazil.

\section{Material and Methods} Study Population and Design

A cross-sectional study using a representative sample of 12-year-old schoolchildren was carried out in Santa Maria, RS, Brazil. There were 3,817 children in this age group in the city. The sample size calculation to assess the prevalence 
of dental caries considered the following parameters: 5\% standard error, 95\% confidence interval, a previous caries prevalence of $39 \%$ (2) and 1.4 for design effect. A rate of $30 \%$ was added to account for losses or refusals. The sample size calculation resulted in a minimum of 667 children. A sample size was also calculated for the assessment of factors associated with the occurrence of dental caries, and the following parameters were considered: $5 \%$ standard error, $80 \%$ test power, $45 \%$ caries prevalence in low-income children (exposed group) and 34\% in high income children (non-exposed group) (2), 95\% confidence interval and ratio of exposed to non-exposed 1:1. A value of $30 \%$ was added for possible losses or refusals, resulting in a minimum of 747 children. The study sample was selected from a multistage sampling procedure, where the first stage was represented by the schools (primary sampling unit) and the second stage by the 12-year-old children enrolled in these schools (secondary sampling unit). First, 20 of 39 eligible public schools were selected, considering their size (number of students) in the city context. All 12-year-old children enrolled in the selected schools $(n=1,911)$ were invited to participate in the study.

\section{Data Collection}

Data regarding oral conditions were obtained by clinical examinations at school. International criteria standardized by the World Health Organization for oral health surveys (12) were used for all dental examinations. The exams were performed using the Community Periodontal Index (CPI) probe, a dental mirror and gauze (12). The presence or absence of dental plaque was assessed according to the Visible Plaque Index (13) and the occurrence of dental caries according to the DMF-T index (12). Four trained and calibrated dentists performed the exams. The process of training and calibration was performed according to the World Health Organization (WHO) in its basic manual for epidemiological studies (12). The inter and intra-examiner Kappa values for DMF-T index ranged from 0.77 to 0.82 and from 0.79 to 0.85 , respectively. These values demonstrate a good to optimal concordance among examiners.

A structured questionnaire including information of child's age and gender, parental education, family income, and race/skin color was sent to children's homes to be answered by their parents or guardians. This questionnaire has been already used in previous studies including this population. The feasibility of the questionnaire was verified replicating it on $10 \%$ of the sample. For data analysis, the variables father's and mother's educational level were categorized as those who completed primary school $(\geq 8$ years) and those with less than eight years of education ( $<8$ years); the variable household income was categorized in tertiles of income: Richest ( $3^{\text {rd }}$ tertile), Intermediate ( $2^{\text {nd }}$ tertile) and Poorest ( $1^{\text {st }}$ tertile).

Context data such as neighborhood income in the community were obtained from official publications of the city (14). The variable was defined by geographical area (district) of the child's school.

\section{Data Analysis}

Data were analyzed using STATA 12.0 software (Stata Corporation, College Station, TX, USA). Initially a descriptive analysis was performed to verify the mean and the prevalence of dental caries (DMF $>0$ ) and untreated dental caries (D>0). Gini Coefficient and SiC index (Significant Caries Index) were used to verify the distribution of the disease. The former is a well-documented index to assess inequality, used mainly to assess income distribution (15). It is a number between 0 and 1 , where zero represents complete equality and 1 complete inequality of the full sample. The second one, SiC index (16), represents the mean DMF-T of the third of the sample presenting the highest disease levels.

Multilevel logistic regression was used to assess associations of the occurrence of dental caries and untreated dental caries with individual and context covariates. The multilevel analysis considered a fixedeffect/random intercept. A multivariate analysis was also running for the outcome 'untreated dental caries'. The first model ("empty model") estimated the proportion of variance arising from each level before the entry of individual and context variables. The second model ("Model 2") included only first-level covariates; in the last model ("Model 3"), the association estimations were adjusted for individual and contextual level characteristics. In all models, Deviance (-2loglikelihood) was used to assess the quality of adjustment; significant changes in the adjustment quality of the models were analyzed using the likelihood ratio test (likelihoodratio).

\section{Ethics}

The Ethics in Research Committee of the Federal University of Santa Maria approved this study protocol. All participants were informed verbally and by letter about the aims of the study. The participant's parents or legal guardians signed a free and informed consent form. Furthermore, all schools received information about the study and agreed to participate.

\section{Results}

A total of 1,134 children comprised the final sample. The response rate was 93\%. Caries prevalence (DMF- $T \geq 1$ ) was $49.9 \%$ (95\% Cl: $45.05 \%$ - 54.77\%), and mean DMF-T was 1.15 (95\% Cl: 1.01-1.29); the prevalence of untreated dental caries was $42.3 \%$ (95\% $\mathrm{Cl}$ : 36.75\%-47.80\%). 
Unequal distribution of dental caries was observed, with a Gini coeficient of 0.66 (Fig. 1) and a SiC index of 2.95.

Table 1 shows the sample description and the prevalence of dental caries, untreated dental caries and mean DMF-T according to clinical, sociodemographic, individual and context characteristics. Most of the participants were white and $45.88 \%$ were male. In addition, when considering family income, a gradient in the occurrence of dental caries was observed. Poorer children presented a higher prevalence of dental caries and a higher mean of DMF-T when compared to those at the intermediate and richest tertiles.

The unadjusted analysis of potential individual and context covariates for the occurrence of dental caries

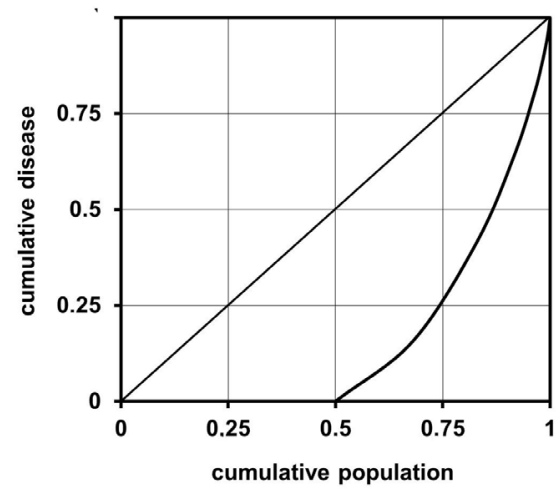

Figure 1. Lorenz curve for the DMF-T distribution (12-year-old children) in Santa Maria, RS, Brazil. Gini coefficient $=0.66$.

Table 1. Percentage of dental caries (DMFT $\geq 1$ ), untreated dental caries ('D' component of DMFT-index $\geq 1$ ) and mean DMFT according to clinical and demographic characteristics of the sample. Santa Maria, RS, Brazil

\begin{tabular}{lllll}
\hline Variables & $\mathrm{N}(\%)$ & DMFT Mean (SE) & DMFT $\geq 1 \mathrm{n}(\%)$ & $\mathrm{D} \geq 1$ \\
$\mathrm{n}(\%)$ &
\end{tabular}

Child covariates ( $1^{\text {st }}$ level)

$$
\begin{aligned}
& \text { Sex }
\end{aligned}
$$

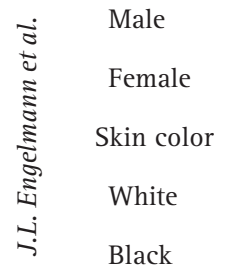

Household Income

Richest (3 $3^{\text {rd }}$ tertile)

Intermediate ( $2^{\text {nd }}$ tertile)

Poorest ( $1^{\text {sttertile) }}$

Father's educational level

With primary education

Without primary education

Mother's educational level

With primary education

Without primary education

Dental Plaque

Yes

No

$523(45.88)$
$611(54.12)$
$851(77.93)$
$245(22.07)$

288 (28.43)

402 (38.63)

346 (32.94)

$628(61.44)$

406 (38.56)

$702(65.55)$

382 (34.45)

582 (51.53)

552 (48.47)

$$
1.16(0.11)
$$

1.14 (0.78)

$1.13(0.06)$

$1.30(0.13)$

$0.82(0.11)$

1.13 (0.06)

$1.47(0.10)$

$0.99(0.08)$

$1.40(0.08)$

$1.03(0.08)$

$1.41(0.07)$

$0.93(0.07)$

$1.38(0.10)$

$261(44.71)$

307 (55.45)

School level (2 ${ }^{\text {nd }}$ level)

Neighborhood mean income ${ }^{\dagger}$

$$
\begin{aligned}
& \geq 75^{\text {th }} \text { quartile } \\
& <75^{\text {th }} \text { quartile }
\end{aligned}
$$$$
342 \text { (30.15) }
$$

$0.86(0.06)$

139 (40.42)

107 (9.34)

792 (69.85)

$1.27(0.05)$

429 (54.01)

218 (41.74)

262 (42.73)

361 (42.49)

110 (44.70)

96 (33.12)

157 (39.61)

184 (52.48)

233 (37.72)

208 (50.68)

$268(38.60)$

198 (51.24)

217 (37.21)

263 (47.66)

* Percentage, mean and standard error (SE) were calculated taken into account the sampling weight; ${ }^{\dagger}$ Neighborhood mean income: represents the mean income from the neighborhood of the school. 
and untreated dental caries are in Table 2. The variables income, mother and father educational level showed a significant association with the occurrence of dental caries and untreated dental caries. Considering the family income, gradient in the occurrence of the disease was observed. For example, children belonging to the $3^{\text {rd }}$ tertile of the sample, representing the richest, and those belonging to the $2^{\text {nd }}$ tertile, representing the middle level, presented a 50\% (OR 0.50: Cl95\% 0.35-0.71) and 39\% (OR 0.61: Cl95\% 0.45-0.82) respectively lower chance to have untreated dental caries when compared to the $1^{\text {st }}$ tertile, which involved the poorest children. The same gradient was observed for the occurrence of dental caries. Moreover, children belonging to families where parents have not completed elementary school presented a 65\% (OR 1.65: $\mathrm{Cl} 95 \%$ 1.26-2.16) and 55\% (OR 1,55: Cl95\% $1,17-2,04)$ higher chance to have untreated dental caries. In addition, children with dental plaque showed a higher chance of having untreated dental caries (OR 1.52:95\% Cl $1.19-1.93)$.

The context variable neighborhood's mean income was also associated with the outcomes. Children belonging to neighborhoods with a lower mean income presented a higher chance of having untreated dental caries (OR $1.98: 95 \% \mathrm{Cl} 1.40-2.80)$ compared to those who lived the richest areas (considering the $75^{\text {th }}$ percentile of income distribution as a threshold).

Table 3 shows the adjusted multilevel model, with

Table 2. Individual and contextual variables associated with dental caries and untreated dental caries - Unadjusted multilevel logistic regression. Santa Maria, RS, Brazil

\begin{tabular}{|c|c|c|c|c|}
\hline Variables & $\mathrm{DMFT} \geq 1 \mathrm{~N}(\%)$ & OR $(95 \% \mathrm{CI})^{*}$ & $\mathrm{D} \geq 1 \mathrm{~N}(\%)$ & OR $(95 \% \mathrm{CI})^{*}$ \\
\hline \multicolumn{5}{|l|}{ Child covariates ( $1^{\text {st }}$ level) } \\
\hline \multicolumn{5}{|l|}{ Sex } \\
\hline Male & $247(47.04)$ & $0.81(0.64-1.02)$ & $218(41.74)$ & $0.95(0.75-1.21)$ \\
\hline Female & $321(52.35)$ & 1 & $262(42.73)$ & 1 \\
\hline \multicolumn{5}{|l|}{ Skin colour } \\
\hline White & $431(50.53)$ & 1 & $361(42.49)$ & 1 \\
\hline Black & $127(51.78)$ & $0.96(0.71-1.29)$ & $110(44.70)$ & $0.99(0.73-1.33)$ \\
\hline \multicolumn{5}{|l|}{ Household Income } \\
\hline Richest (3 ${ }^{\text {rd }}$ tertile) & $119(41.06)$ & $0.55(0.39-0.78)$ & $96(33.12)$ & $0.50(0.35-0.71)$ \\
\hline Intermediate ( $2^{\text {nd }}$ tertile) & 196 (49.09) & $0.72(0.53-0.97)$ & $157(39.61)$ & $0.61(0.45-0.82)$ \\
\hline Poorest ( $1^{\text {st }}$ tertile) & $202(57.65)$ & 1 & $184(52.48)$ & 1 \\
\hline \multicolumn{5}{|l|}{ Father's educational level } \\
\hline With primary education & $284(45.88)$ & 1 & $233(37.72)$ & 1 \\
\hline Without primary education & $238(57.67)$ & $1.64(1.26-2.15)$ & $208(50.68)$ & $1.65(1.26-2.16)$ \\
\hline \multicolumn{5}{|l|}{ Mother's educational level } \\
\hline With primary education & 325 (46.70) & 1 & $268(38.60)$ & 1 \\
\hline Without primary education & $227(58.48)$ & $1.59(1.21-2.09)$ & $198(51.24)$ & $1.55(1.17-2.04)$ \\
\hline \multicolumn{5}{|l|}{ Dental Plaque } \\
\hline Without & $261(44.71)$ & 1 & $217(37.21)$ & 1 \\
\hline With & $307(55.45)$ & $1.53(1.20-1.94)$ & $263(47.66)$ & $1.52(1.19-1.93)$ \\
\hline \multicolumn{5}{|l|}{ School level ( $2^{\text {nd }}$ level) } \\
\hline \multicolumn{5}{|l|}{ Neighborhood mean income ${ }^{\dagger}$} \\
\hline$\geq 75^{\text {th }}$ quartile & $139(40.42)$ & 1 & 107 (30.99) & 1 \\
\hline$<75^{\text {th }}$ quartile & $429(54.01)$ & $1.73(1.29-2.31)$ & $373(47.15)$ & $1.98(1.40-2.80)$ \\
\hline
\end{tabular}

* Unadjusted multilevel logistic regression. ${ }^{+}$Neighborhoods mean income: represent the mean income from the neighborhood of the school. 
the individual and context variables associated with the outcome "occurrence of untreated caries". All the variables that presented association in the unadjusted analysis remained significantly associated. Only maternal schooling was not included in the model, because it presented a strong correlation with the variable father schooling.

When the contextual variable neighborhood's mean income was included in the multilevel adjusted model ("Full Model"), it also remained associated with the outcome. The chance of occurring untreated dental caries was $70 \%$ higher for children from neighborhoods where the mean income was less than the 75th percentile of income distribution, compared to those from neighborhoods with the mean income exceeding or equal to this value $(95 \%$ Cl 1.70 OR 1.19-2.43).

\section{Discussion}

This study assessed the association of dental caries and untreated dental caries with individual and context socioeconomic factors. The main result is that children belonging to contexts with better socioeconomic profiles had lower chances of presenting dental caries.

A high dental caries rate has been reported by studies in communities with poor socioeconomic profiles $(9,10)$ and this association is the source of health inequalities in such populations (17). Nevertheless, there is evidence that individuals from groups of greater risk are more likely to develop oral diseases (11).

Furthermore, there are inequities in the distribution of disease. It has been seen that a larger portion of the population is free of dental caries and higher levels of

Table 3. Individual and contextual variables associated with dental caries and untreated caries - Adjusted multilevel logistic regression. Santa Maria, Brazil

\begin{tabular}{|c|c|c|c|}
\hline \multirow{2}{*}{ Fixed Component } & Model 1 (“empty”)* & Model 2* (“individual”) & Model 3 ("full")* \\
\hline & OR (CI95\%) & OR (CI95\%) & OR (CI95\%) \\
\hline Intercept & $0.78(0.63-0.95)$ & $0.46(0.27-0.78)$ & $0.29(0.16-0.53)$ \\
\hline \multicolumn{4}{|l|}{ Child covariates (1st level) } \\
\hline \multicolumn{4}{|l|}{ Skin color } \\
\hline White & & 1 & 1 \\
\hline Black & & $0.73(0.52-1.03)$ & $0.72(0.52-1.01)$ \\
\hline \multicolumn{4}{|l|}{ Household Income } \\
\hline Richest ( $3^{\text {rd }}$ tertile) & & $0.54(0.37-0.79)$ & $0.58(0.40-0.85)$ \\
\hline Intermediate ( $2^{\text {nd }}$ tertile) & & $0.63(0.45-0.87)$ & $0.65(0.47-0.89)$ \\
\hline Poorest ( $1^{\text {st }}$ tertile) & & 1 & 1 \\
\hline \multicolumn{4}{|l|}{ Father's educational level } \\
\hline With primary education & & 1 & 1 \\
\hline Without primary education & & $1.44(1.06-1.94)$ & $1.41(1.04-1.90)$ \\
\hline \multicolumn{4}{|l|}{ Dental plaque } \\
\hline No & & 1 & 1 \\
\hline Yes & & $1.68(1.28-2.21)$ & $1.72(1.31-2.25)$ \\
\hline \multicolumn{4}{|l|}{ School level (2 $2^{\text {nd }}$ level) } \\
\hline Neighborhood's mean income ${ }^{\dagger}$ & & & 1 \\
\hline \multicolumn{4}{|l|}{$\geq 75^{\text {th }}$ quartile } \\
\hline$<75^{\text {th }}$ quartile & & & $1.70(1.19-2.43)$ \\
\hline \multicolumn{4}{|l|}{ Random Component } \\
\hline Deviance (-2loglikelihood) & 1529.205 & 1226.1596 & 1218.8879 \\
\hline
\end{tabular}

Model 1 ('null') represents the unconditional model; Model 2 represents individual covariates; Model 3 ('full') represents subject and school level covariates; ${ }^{\dagger}$ Neighborhood’s mean income: represent the mean income from the neighborhood of the school. ${ }^{\dagger}$ Represents average income from the neighborhood; 
disease are concentrated in a minority of them $(2,18)$. In the present study, the Gini Coefficient (15) was used to verify the degree of inequality, resulting in a value of 0.66 (Fig. 1). This value next to 1 represents uneven distribution of dental caries in the sample. Other studies used this coefficient, showing similar results with respect to inequality (17). Similarly, the SiC Index (16) resulted in 2.95, higher than the 1.15 mean DMF-T observed in the overall sample. This result also demonstrated that there is a small part of the population with a higher rate of disease. In the present data, both indicators confirmed the occurrence of inequality in caries distribution. The same pattern was found in another study (19).

An association between the presence of dental plaque and the occurrence of dental caries and untreated caries was observed. Therefore, the presence of bacterial biofilm increases the chance of the outcome. Such finding suggests that good habits and especially the quality of oral hygiene can reduce the severity of the disease $(20,21)$. However, isolated plaque control measures and guidance directed are admittedly inadequate, since socioeconomic conditions were pointed out as distal determinants of the development of caries, modulating the exposure to risk and protection factors, in addition to the oral health services (22).

This study also verified influence of family income on the occurrence of untreated dental caries. This variable showed association with the outcome, even after adjusting for other variables. Children belonging to richer portions of the sample showed a lower chance to have untreated caries when compared to the poorest one. These results corroborate other studies that also evaluated the effect of socioeconomic factors on dental caries $(2,17)$ and showed that socioeconomic inequalities remain as important factors that influence oral health.

Regarding the father and mother educational level, children from families whose parents have no primary education had a greater chance to have untreated caries and DMF- $\mathrm{Z} \geq 1$ compared with children whose parents had primary education or more. These findings indicate that the level parental education can influence the occurrence of caries in children in the early years (7), as well as in adolescence, which has been previously reported (2).

The influence of socioeconomic factors on the occurrence of dental caries in children and adolescents has been reported $(7,17)$, although few have considered the multilevel effect of context characteristics of the children's schools.

When the contextual variable neighborhood mean income was included in the model, it remained associated with the outcome, even when adjusted for all other variables. These results corroborate other studies $(9,11)$ confirming that socioeconomic inequalities concerning the context remain as important factors of influence on the oral health of children.

Different mechanisms have been proposed to describe the possible effects of socioeconomic status on health outcomes (23). Material deprivation or psychosocial pathways have been described as possible theoretical explanations regarding the connection between socioeconomic status and oral health (17). They might have important effects on the individual's lifestyle decisions. One possible explanation is that the lack of economic resources and empowerment of deprived individuals do not allow them to make healthy choices, which make them more likely to engage in deleterious behaviors affecting their oral health (24). Otherwise, the influence of socioeconomic factors on oral health may explain their psychosocial effects, as for example stress and coping styles across different social groups (25).

Disparities in the distribution of caries have been demonstrated even with the evidence of a decrease in the prevalence of the disease in recent decades (5). This phenomenon has been regarded as one of the biggest challenges on the oral health promotion agenda (3). Studies that take into account individual and context determinants to explain the distribution of dental caries have been suggested $(10,11)$. These results may be used as a basis for planning public health strategies and health promotion actions aimed at reducing health inequalities across population groups.

Therefore, multilevel models allow identifying context factors that may have an influence on the occurrence of dental caries (8). Studies using such analytical approach are important to identify the underlying factors or population groups that require greater attention from health sectors.

The present study presents some limitations. It evaluated only schoolchildren from public schools, and did not consider private schools. However, the sample may be considered heterogeneous with regards to socioeconomic characteristics, because it included children belonging to different levels of education and socioeconomic classes. Additionally, it must be considered that $80 \%$ of the children are enrolled in public schools of the city (26).

The cross-sectional design's limitation in determining causal relationships is well known, because of its inability to establish temporal relations between causes and effects. Even so, this study highlights that the most employed socioeconomic indicators in studies present little variation through life (22).

Despites these limitations, it is believed that the present results bring important contribution for the population. The study identified socioeconomic inequalities at both individual and context level as a determinant for the occurrence of dental caries. Such association may be used 
as important information to plan community activities and oral health promotion. These strategies should consider the individual and context socioeconomic factors to reduce the levels of dental caries and inequalities in its distribution in disadvantaged groups.

\section{Resumo}

Esta pesquisa teve como objetivo avaliar a associação entre cárie dental e fatores socioeconômicos individuais e contextuais em crianças de 12 anos de idade. Uma amostra representativa de 1.134 crianças matriculadas em escolas públicas de Santa Maria, RS, foi obtida a partir de uma amostragem aleatória em duplo estágio. Quatro dentistas calibrados examinaram os participantes nas escolas. Foram avaliados dados sobre cárie dentária (indice CPO-D) e placa dentária (presente ou ausente). Os pais ou responsáveis pelos adolescentes responderam questionários sobre status socioeconômico e sociodemográficos. Variáveis contextuais também foram coletadas através de publicações oficiais do municipio. Os dados foram analisados utilizando-se modelos multiniveis de regressão logistica. A prevalência de cárie da amostra (CPO-D $\geq 1$ ) foi 49.9\% (95\%lC: 45.05\% - 54.77), e a média de CPO-D foi de 1.15 (95\%IC: 1.01-1.29) com 0.068 de erro padrão. As crianças do $3^{\circ}$ e $2^{\circ}$ tercil de renda representado pelas categorias ricas e intermediárias apresentaram respectivamente $50 \%$ (OR 0,50: IC95\% 0,35-0,71) e 39\% (OR 0,61: IC95\% 0,45-0,82) menor chance de apresentarem cárie não tratada em comparação com a porção mais pobre da amostra representada pelo $1^{\circ}$ tercil de renda. Em relação à variável contextual "renda média do bairro", crianças que viviam em bairros com menor renda apresentaram uma chance $70 \%$ (OR 1,70: IC95\% 1,19-2,43) maior de ter cárie dentária não tratada, quando comparadas com aquelas que viviam em bairros de maior renda. Desigualdades na distribuição da cárie dentária continuam afetando as crianças dos perfis socioeconômicos mais pobres. Os resultados mostram a necessidade de planejamento de intervenções públicas que visem a promoção da saúde bucal que levem em conta as caracteristicas socioeconômicas individuais e contextuais.

\section{References}

1. Fejerskov O, Nyvad B, Kidd E, eds. Dental caries: the disease and its clinical management. 3rd ed. Hoboken, NJ: Wiley Blackwell, 2015.

2. Piovesan C, Mendes FM, Antunes JLF, Ardenghi, TM. Inequalities in the distribution of dental caries among 12-year-old Brazilian schoolchildren. Braz Oral Res 2011;25:69-75.

3. Pitts N, Amaechi B, Niederman R, Acevedo A.M, Vianna R, Ganss C, et al.. Global oral health inequalities: dental caries task group - Research agenda. Adv Dent Res 2011;23 211-220.

4. Brazil. Ministry of Health. Project SB Brazil 2010. Oral health conditions of the Brazilian population 2010. Main outcomes. Brasilia, 2010.

5. Narvai PC, Frazão P, Castellanos RA. Decline in caries experience in permanent teeth of Brazilian schoolchildren in the late twentieth century. Rev Odontol Soc 1999;1:25-29.

6. Antunes JLF; Jahn GM, Camargo AM. Increasing inequalities in the distribution of dental caries in Brazilian context in Finland. Community Dent Health 2005;22:94-100.

7. Oliveira LB, Sheiham A, Bönecker M. Exploring the association of dental caries with social factors and nutritional status in Brazilian preschool children. Eur J Oral Sci 2008;116:37-43.
8. Diez-Roux AV. Multilevel analysis in public health research. Annual Review Public Health. 200;21:171-192

9. Antunes JLF, Peres MA, de Campos Mello TR, Waldman EA. Multilevel assessment of determinants of dental caries experience in Brazil. Community Dent Oral Epidemiol 2006;34:146-152.

10. Pattussi MP, Hardy R, Sheiham A. The potential impact of neighborhood empowerment on dental caries among adolescents. Community Dentistry and Oral Epidemiology 2006;34:344-350.

11. Tellez M, Sohn W, Burt BA, Ismail Al. Assessment of the relationship between neighborhood characteristics and dental caries severity among low-income African-Americans: a multilevel approach. J Public Health Dent 2006;66:30-36.

12. WHO. Oral Health surveys, basic methods. Geneva 1997.

13. Ainamo J, Bay I. Problems and proposals for recording gingivitis and plaque. International Dental Journal 1975;25:229-235.

14. IBGE. Results of the sample - Work and Income 2010 [Latest access February 3, 2016]. Available from: http://www.sidra.ibge.gov.br

15. Kawachi I, Kennedy BP. The relationship of income inequality to mortality: does the choice of indicator matter? Soc Sci Med 1997;45:1121-1127.

16. Bratthall D. Introducing the Significant Caries Index together with a proposal for a new global oral health goal for 12-year-olds. Int Dent $J$ 2000;50:378-384.

17. Pattussi MP, Marcenes W, Croucher R, Sheiham A. Social deprivation, income inequality, social cohesion and dental caries in Brazilian schoolchildren. Soc Sci Med 2001;53:915-925.

18. Hugo FN, Vale GC, Ccahuana-Vásquez RA, Cypriano S, Sousa MLR. Polarization of dental caries among individuals aged 15 to 18 Years. J Appl Oral Sci 2007;15:253-258.

19. Antunes JLF, Narvai PC, Nugent ZJ. Measuring inequalities in the distribution of dental caries. Community Dent Oral Epidemiol 2004;32:41-48.

20. Agostini BA, Machry RV, Teixeira CRS, Piovesan C, Oliveira MDM, Bresolin CR, et al.. Self-perceived health influences tooth brushing in preschool children. Braz Dent J 2014;25:248-252.

21. Meurman PK, Pienihäkkinen K. Factors associated with caries increment: a longitudinal study from 18 months to 5 years of age. Caries Research 2010;44:519-522.

22. Boing $A F$, Bastos JL, Peres KG, Antunes JLF, Peres MA. Social determinants of health and dental caries in Brazil: a systematic review of the literature between 1999 and 2010. Res Bras Epidemiol 2014;102115.

23. Kawachi I, Kennedy BP. Income inequality and health: pathways and mechanisms. Health Serv Res 1999;34: 215-227.

24. Braveman PA, Cubbin C, Egerter $\mathrm{S}$, et al.. Socioeconomic status in health research: one size does not fit all. JAMA 2005;294:2879-2888.

25. Celeste RK, Nadanovsky P. How much of the income inequality effect can be explained by public policy? Evidence from oral health in Brazil. Health Policy 2010;97:250-258.

26. CRE. Regional Coordination of Education 08 - Santa Maria. [Latest access February 3, 2016]. Available from: http://www.educacao.rs.gov. $\mathrm{br} / \mathrm{pse} / \mathrm{html} / \mathrm{cre} . j \mathrm{sp} ? \mathrm{ACAO}=\mathrm{aca0} 2 \mathrm{tCRE}=08$

Received August 2, 2015 Accepted November 10, 2015 